\title{
Anaesthetics and plants: from sensory systems to cognition-based adaptive behaviour
}

\author{
František Baluška ${ }^{1} \cdot$ Ken Yokawa ${ }^{2}$ \\ Received: 14 September 2020 / Accepted: 25 November 2020 / Published online: 19 January 2021 \\ (C) The Author(s) 2021
}

\begin{abstract}
Plants are not only sensitive to exogenous anaesthetics, but they also produce multitudes of endogenous substances, especially when stressed, that often have anaesthetic and anelgesic properties when applied to both humans and animals. Moreover, plants rely on neurotransmitters and their receptors for cell-cell communication and integration in a similar fashion to the use of neural systems in animals and humans. Plants also use their plant-specific sensory systems and neurotransmitter-based communication, including long-distance action potentials, to manage stress via cognition-like plant-specific behaviour and adaptation.
\end{abstract}

Keywords Adaptive behaviour $\cdot$ Anaesthetics $\cdot$ Cell biology $\cdot$ Plant cognition $\cdot$ Sensory systems

\begin{abstract}
Motto
Claude Bernard: ' ... what is alive must sense and can be anaesthetised, the rest is dead.'

(Bernard 1878; Grémiaux et al. 2014; Kelz and Mashour 2019).
\end{abstract}

\section{Introduction}

Ever since Aristotle placed plants outside the realm of sensitive organisms due to their immobility and apparent lack of sensation, plants have been considered somewhere in between living and non-living systems (Lindsay 1876; Ingensiep 2001; Mesaroș 2014; Linson and Calvo 2020). Immanuel Kant considered plants close to inorganic minerals due to their apparently senseless nature (Ingensiep 2001, p. 310). Later, Erasmus, Charles and Francis Darwin, together with Wilhelm Pfeffer, Gottlieb Haberlandt, Bohumil Nemec and

Handling Editor: Handling Editor: Peter Nick

František Baluška

baluska@uni-bonn.de

Ken Yokawa

yokawaken@mail.kitami-it.ac.jp

1 IZMB, University of Bonn, Kirschallee, 53115 Bonn, Germany

2 Faculty of Engineering, Kitami Institute of Technology, Hokkaido 090-8597, Japan
Jagadis Bose, contradicted these views and believed plants to be actively living organisms based on their plant-specific sensory systems (Francé 1905; Stahlberg 2006). In 2005, the plant neurobiology initiative was established in Firenze (Italy) and was met with opposing arguments stemming from the view that plants lack agency, cognition and conscious behaviour (Alpi et al. 2007; Taiz et al. 2019; Draguhn et al. 2020). To address such opposition, first, it has never been claimed that plants have true neurons or neuronal synapses. However, plant cells have many features and properties that were originally attributed to neurons (Baluška 2010), including excitable plasma membranes with voltage-gated ion channels that can support plant-specific action potentials and synaptic-like endocytic vesicle recycling. In addition, in the root apex transition zone, cell-cell adhesion domains structurally and functionally resemble neuronal synaptic domains and have thus been introduced as plant-specific synaptic domains (Baluška et al. 2005). Second, since the field of neuroscience started with studies of human and animal brains, thus many terms which were originally used in a brain-specific manner turned out to have more general applications. This causes issues with terminology and comprehension (Maher 2020) when similar and/or analogous molecules, structures and processes are discovered later in other organisms, especially in plants.

Sensory systems, agency, cognition, behaviour and adaptation are fundamental attributes of all living organisms (Kováč 2006; Baluška and Mancuso 2009; Baluška et al. 2018; Calvo et al. 2020a, b; Trewavas and Baluška 2011; Witzany and Baluška 2012; Leopold 2014; Baluška and 
Levin 2016; van Duijn 2017, Lamme 2018; Reber and Baluška 2020). This follows from Darwinian evolution, in which all organisms, extinct and current, are part of the same evolutionary systems and utilise the same biological life principles. Of course, there are significant differences in these fundamental attributes between different types of organisms, but organism-specific versions are present in all organisms (Bernard 1878; Baluška and Mancuso 2009, 2020a,b; Baluška and Levin 2016; Linson and Calvo 2020; Reber and Baluška 2020). If we continue to maintain a Darwinian evolutionary position (Eisenstein et al. 2016), we must expect that all organisms rely on these faculties. In words of William James, ' $\ldots$ if evolution is to work smoothly, consciousness in some shape must have been present at the very origins ...' (James 1890, p. 149).

\section{Plants and anaesthetics}

Plants are emerging as very sensitive organisms with respect to anaesthetics. Importantly, anaesthetics can prevent the movement of animals, humans and plants via their quick prevention of action potentials (for plants, see Volkov et al. 2010, 2014; Grémiaux et al. 2014; Hedrich and Neher 2018; Yokawa et al. 2018, 2019; Pavlovič et al. 2020). Anaesthesia in humans induces a loss of awareness, which could also be hypothesised to occur for plants. Sensory events received at the plasma membrane (Matzke et al. 2019) are first translated into bioelectric signals (Levin 2019), which are later transformed into chemical signals acting in networks present not only in animals and humans (DeWeese and Zador 2006; Vosshall and Carandini 2009) but also in plants (Hedrich 2012; Reyer et al. 2020).

Draguhn et al. (2020) claim that anaesthetics affect numerous proteins and molecules. This seems to be true, but is not a relevant argument for the exclusion of plants in experimental studies aiming to illuminate the mysteries underlying their actions that lead to general immobility, weakening pain perception and a loss of consciousness. In addition, the induction of immobility by anaesthetics has the same biological basis in humans, animals and plants. As in animals, the blockage of action potentials stops organ movement in plants (Yokawa et al. 2018; Pavlovič et al. 2020). Plants have emerged as valid and relevant experimental systems in which to investigate the still-elusive primary anaesthetic targets that suppress plant action potentials (Yokawa et al. 2019). A recent paper reported that general anaesthetics target PLD2 localised to neuronal lipid rafts (Pavel et al. 2020). Anaesthetics are well known to associate with and to perturb lipid rafts (Weinrich and Worcester 2013; Kinoshita et al. 2019; Pavel et al. 2020). Importantly, PLD $\delta$ localises to lipid rafts in Arabidopsis (Xing et al. 2019), and there are several molecular tools and transgenic lines for use in studying the emerging roles of lipid rafts as cellular targets of anaesthetics ( $\mathrm{Li}$ et al. 2012; Wang et al. 2015; Zhao et al. 2015a,b; Xue et al. 2018; Xing et al. 2019; Jaillais and Ott 2020). In root apices, cells in the transition zone (Fig. 1) show abundant lipid rafts with high lipid order under their cross-walls (Zhao et al. 2015a,b), which are active in the endocytic vesicle recycling (Baluška et al. 2005; Baluška and Mancuso 2013), as well as synchronous oscillations of several processes (Baluška and Mancuso 2013).

With respect to pain perception, it is obvious that plants do not perceive noxious stimuli in the same way as animals and humans. Obviously, plants do not have brain enclosed by a skull. However, in order to survive and adapt effectively, plants still need to be able to recognise what is dangerous and have evolved their own plant-specific sensory systems to do so. Anaesthetics are especially relevant in this respect, as plants produce a large variety of chemicals and substances when wounded or heavily stressed (Tsuchiya 2017) that have known anaesthetic effects on humans and animals (Baluška

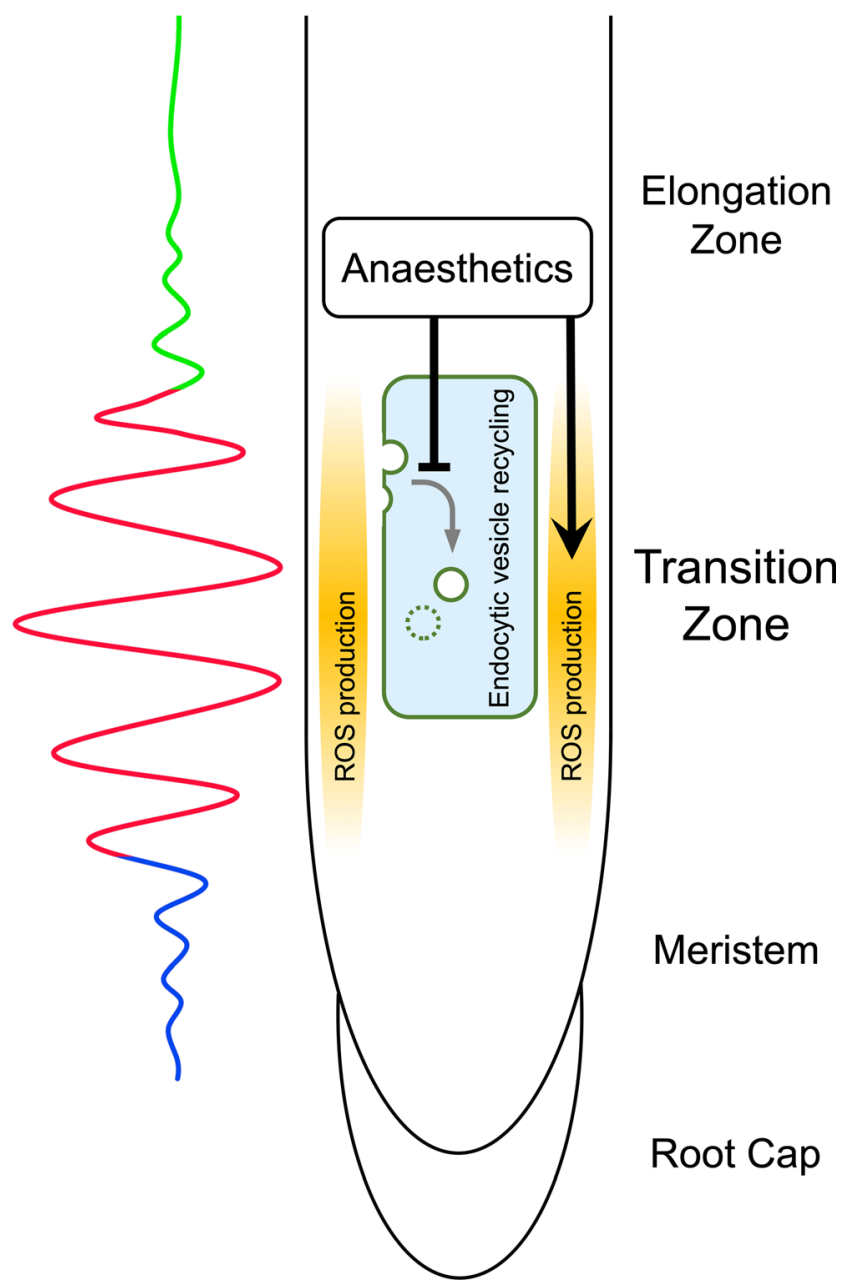

Fig. 1 Schematic view of the root apex. The transition zone is the most sensitive root apex zone to anaesthetics which inhibit endocytic vesicle recycling and induce ROS imbalances (Yokawa et al. 2018, 2019). Cells in this bioelectrically active and oscillatory zone have high oxygen demand related to endocytic vesicle recycling (Baluška and Mancuso 2013) and are typical with high amounts of well-ordered lipid rafts (Zhao et al. 2015a,b). For more details, see Baluška and Mancuso (2013) 
et al. 2016). For example, stress phytohormones such as ethylene and methyl salicylate are also anaesthetics (Campagna et al. 2003; Roohi and Imanpoor 2015; Baluška et al. 2016). Plant-derived menthol exhibits similar general anaesthetic effects as propofol (Watt et al. 2008). In addition, ethylene was used in human surgeries and emerged as a leading anaesthetic in the early twentieth century (Johnstone 1927; Dillard 1930), with its disuse in surgeries resulting from a series of accidents. Numerous other substances synthesised by plants, including diverse terpenoids, alkaloids and flavonoids, have anaesthetic activities (Tsuchiya 2017). Perhaps it is not surprising that ethylene and other plant-produced anaesthetics are particularly abundant in mature fruits (Baluška et al. 2016), which have been evolved by plants to be eaten by frugivores for the purpose of plant seed dispersal.

\section{Neurotransmitters and their receptors in plants}

Ligand-gated ion channels underlie both excitatory and inhibitory transmission in animal nervous systems, in which glutamate and GABA act as specific ligands. Similarly, in plants, glutamate acts as an excitatory and GABA as an inhibitory ligand for plant-specific versions of glutamate and GABA receptors. More specifically, control of plasma membrane excitability is accomplished via glutamate and GABA in both animals and plants, where glutamate increases and GABA decreases membrane excitability via ion channel control (for plants see Ramesh et al. 2015, 2017; Žárský 2015). Glutamate and GABA receptors are often characterised as anaesthetic targets, and plant-derived bicuculline regulates mammalian GABA receptors as well as GABA signalling in plants (Ramesh et al. 2015, 2017; Žárský 2015). In addition, GABA acts as a ligand of the voltage-gated potassium channel GORK in plants (Adem et al. 2020), thereby shaping action potentials in plants (Cuin et al. 2018). Glutamate is also triggering action potentials in plants (Felle and Zimmermann 2007; Stolarz et al. 2010; Koselski et al. 2020). As with bicuculline control of GABA neurotransmission, glutamate neurotransmission can be controlled by plant-derived molecules such as berberine, an isoquinoline plant alkaloid (Lin et al. 2013). Interestingly, recent evolutionary analysis of glutamate receptors suggests that glutamate signalling involving plant glutamate receptors (Weiland et al. 2016; Wudick et al. 2018; Qiu et al. 2020) may have predated signalling via neuronal iGlur glutamate receptors in animals and humans (see Figure 1 in Stroebel and Paoletti 2020). Neuron-like electrical long-distance signalling in plants (Mousavi et al. 2013; Hedrich et al. 2016; Toyota et al. 2018; Muday and Brown-Harding 2018; Kumari et al. 2019; Reyer et al. 2020) assembles plant bodies into coherent units acting as single cognitive selves (Baluška and Mancuso 2020a). Beyond GABA and glutamate, plants also use a diverse array of other neurotransmitters for signalling and communication (Baluška et al. 2020).

\section{Sensory systems of plants support cognition-based and intelligent plant behaviour}

Currently, it is accepted without a doubt that plants use exquisitely sensitive sensory systems to adapt to an ever-changing environment despite their immobility. Besides the unique plant senses that allow, for example, plant roots to navigate towards water or away from salty areas and light (Takahashi and Scott 1991; Galvan-Ampudia et al. 2013; Yokawa et al. 2014; Mo et al. 2015; Dietrich 2018), all senses known in humans and animals are present as plant-specific versions in plants (Francé 1905; Weiler 2003; Gagliano et al. 2017; Mescher and De Moraes 2015; Rodrigo-Moreno et al. 2017; Baluška and Mancuso 2016; Sopory 2019). Plant sensory systems thus support putative plant-specific versions of cognition and intelligence.

\section{Conclusions}

Plants emerge as truly living organisms with all related cognitive and behavioural consequences. The use of anaesthetics promises to be an excellent tool for probing not only the possibility of cognition, and other (awareness) functions in plants, but also the elusive molecular targets of substances producing analgesic and anaesthetic effects in humans (Baluška et al. 2016; Kelz and Mashour 2019). Considering plants as organisms devoid of sensory and cognitive faculties has serious consequences for our technology-based exploitation of trees and forests, which are critical systems contributing to climate stability (Baluška and Mancuso 2020b). Preserving healthy forests is our prime task for preventing environmental collapses in the future. Understanding that plants are truly living organisms, with all the associated cognitive abilities, will help us to forge a transformation of the biological sciences, as well as to support the preservation of our current life-friendly climate.

Acknowledgements FB acknowledges the foundation 'Stiftung Zukunft jetzt!' (Munich, Germany) for support.

Author contribution Both authors planned, discussed and wrote the paper.

Funding Open Access funding enabled and organized by Projekt DEAL.

\section{Compliance with ethical standards}

Conflict of interest The authors declare that they have no conflicts of interest. 
Open Access This article is licensed under a Creative Commons Attribution 4.0 International License, which permits use, sharing, adaptation, distribution and reproduction in any medium or format, as long as you give appropriate credit to the original author(s) and the source, provide a link to the Creative Commons licence, and indicate if changes were made. The images or other third party material in this article are included in the article's Creative Commons licence, unless indicated otherwise in a credit line to the material. If material is not included in the article's Creative Commons licence and your intended use is not permitted by statutory regulation or exceeds the permitted use, you will need to obtain permission directly from the copyright holder. To view a copy of this licence, visit http://creativecommons.org/licenses/by/4.0/.

\section{References}

Adem GD, Chen G, Shabala L, Chen ZH, Shabala S (2020) GORK channel: a master switch of plant metabolism? Trends Plant Sci 25(5):434-445

Alpi A, Amrhein N, Bertl A, Blatt MR, Blumwald E, Cervone F, Dainty J, de Michelis MI, Epstein E, Galston AW, Goldsmith MHM, Hawes C, Hell R, Hetherington A, Hofte H, Juergens G, Leaver CJ, Moroni A, Murphy A, Oparka K, Perata P, Quader H, Rausch T, Ritzenthaler C, Rivetta A, Robinson DG, Sanders D, Scheres B, Schumacher K, Sentenac H, Slayman CL, Soave C, Somerville C, Taiz L, Thiel G, Wagner R (2007) Plant neurobiology: no brain, no gain? Trends Plant Sci 12(4):135-136

Baluška F (2010) Recent surprising similarities between plant cells and neurons. Plant Signal Behav 5:87-89

Baluška F, Levin M (2016) On having no head: cognition throughout biological systems. Front Psychol 7:902

Baluška F, Mancuso S (2009) Deep evolutionary origins of neurobiology: turning the essence of 'neural' upside-down. Commun Integr Biol 2: $60-65$

Baluška F, Mancuso S (2013) Root apex transition zone as oscillatory zone. Front Plant Sci 4:354

Baluška F, Mancuso S (2016) Vision in plants via plant-specific ocelli? Trends Plant Sci 21(9):727-730

Baluška F, Mancuso S (2020a) Individuality, self and sociality of vascular plants. Phil Transact Royal Soc B Biol Sci, In press

Baluška F, Mancuso S (2020b) Plants, climate and humans: plant intelligence changes everything. EMBO Rep 21(3):e50109

Baluška F, Volkmann D, Menzel D (2005) Plant synapses: actin-based adhesion domains for cell-to-cell communication. Trends Plant Sci 10:106-111

Baluška F, Yokawa K, Mancuso S, Baverstock K (2016) Understanding of anesthesia - why consciousness is essential for life and not based on genes. Commun Integr Biol 9(6):e1238118

Baluška F, Gagliano M, Witzany G (2018) Memory and learning in plants. Springer Nature

Baluška F, Mukherjee S, Ramakrishna A (2020) Neurotransmitters in plant signaling and communication. Springer Nature

Bernard C (1878) Lectures on phenomena of life common to animals and plants. Ballliere, and Son, Paris

Bos AP (2010) Aristotle on the differences between plants, animals, and human beings and on the elements as instruments of the soul (de anima 2.4.415b18). Rev Metaphys 63(4):821-841

Calvo P, Gagliano M, Souza GM, Trewavas A (2020a) Plants are intelligent, here's how. Ann Bot 125(1):11-28
Calvo P, Baluška F, Trewavas A (2020b) Integrated information as a possible basis for plant consciousness. Biochem Biophys Res Commun In press

Campagna JA, Miller KW, Forman SA (2003) Mechanisms of actions of inhaled anesthetics. New Engl J Med 348:2110-2124

Cuin TA, Dreyer I, Michard E (2018) The role of potassium channels in Arabidopsis thaliana long distance electrical signalling: AKT2 modulates tissue excitability while GORK shapes action potentials. Int J Mol Sci 19(4):926

DeWeese MR, Zador A (2006) Efficiency measures. Nature 439(7079): 920-921

Dietrich D (2018) Hydrotropism: how roots search for water. J Exp Bot 69(11):2759-2771

Dillard MM (1930) Ethylene - the new general anesthetic. J Natl Med Assoc 22(1):10-11

Draguhn A, Mallatt JM, Robinson DG (2020) Anesthetics and plants: no pain, no brain, and therefore no consciousness. Protoplasma In press

van Duijn M (2017) Phylogenetic origins of biological cognition: convergent patterns in the early evolution of learning. Interface Focus 7(3):20160158

Eisenstein EM, Eisenstein DL, Sarma JSM (2016) An exploration of how to define and measure the evolution of behavior, learning, memory and mind across the full phylogenetic tree of life. Commun Integr Biol 9(3):e1166320

Felle HH, Zimmermann MR (2007) Systemic signalling in barley through action potentials. Planta 226(1):203-214

Francé RH (1905) Germs of mind in plants (translated by Simons AM). Charles Kerr Company, Chicago

Gagliano M, Grimonprez M, Depczynski M, Renton M (2017) Tuned in: plant roots use sound to locate water. Oecologia 184(1):151-160

Galvan-Ampudia CS, Julkowska MM, Darwish E, Gandullo J, Korver RA, Brunoud G, Haring MA, Munnik T, Vernoux T, Testerink C (2013) Halotropism is a response of plant roots to avoid a saline environment. Curr Biol 23(20):2044-2050

Grémiaux A, Yokawa K, Mancuso S, Baluška F (2014) Plant anesthesia supports similarities between animals and plants. Claude Bernard's forgotten studies. Plant Signal Behav 9:27886

Hedrich R (2012) Ion channels in plants. Physiol Rev 92(4):1777-1811

Hedrich R, Neher E (2018) Venus flytrap: how an excitable, carnivorous plant works. Trends Plant Sci 23(3):220-234

Hedrich R, Salvador-Recatalà V, Dreyer I (2016) Electrical wiring and long-distance plant communication. Trends Plant Sci 21(5):376387

Ingensiep HW (2001) Geschichte der Pflanzenseele. Alfred Kröner Verlag, Stuttgart

Jaillais Y, Ott T (2020) The nanoscale organization of the plasma membrane and its importance in signaling: a proteolipid perspective. Plant Physiol 182(4):1682-1696

James W (1890) The principles of psychology. Henry Holt and Company

Johnstone GA (1927) Advantages of ethylene-oxygen as a general anesthetic. Cal West Med 27(2):216-218

Kelz MB, Mashour GA (2019) The biology of general anesthesia from Paramecium to primate. Curr Biol 29(22):R1199-R1210

Kinoshita M, Chitose T, Matsumori N (2019) Mechanism of local anesthetic-induced disruption of raft-like ordered membrane domains. BBA - General Subjects 1863:1381-1389

Koselski M, Wasko P, Derylo K, Tchorzewski M, Trebacz K (2020) Glutamate-induced electrical and calcium signals in the moss Physcomitrella patens. Plant Cell Physiol:61 In press

Kováč L (2006) Life, chemistry and cognition: conceiving life as knowledge embodied in sentient chemical systems might provide new insights into the nature of cognition. EMBO Rep 7(6):562-566 
Kumari A, Chételat A, Nguyen CT, Farmer EE (2019) Arabidopsis H+ATPase AHA1 controls slow wave potential duration and woundresponse jasmonate pathway activation. Proc Natl Acad Sci U S A 116(40):20226-20231

Lamme VAF (2018) Challenges for theories of consciousness: seeing or knowing, the missing ingredient and how to deal with panpsychism. Philos Trans R Soc Lond Ser B Biol Sci 373(1755):20170344

Leopold AC (2014) Smart plants: memory and communication without brains. Plant Signal Behav 9(10):e972268

Levin M (2019) The computational boundary of a "self": developmental bioelectricity drives multicellularity and scale-free cognition. Front Psychol 10:2688

Li R, Liu P, Wan Y, Chen T, Wang Q, Mettbach U, Baluska F, Samaj J, Fang X, Lucas WJ, Lin J (2012) A membrane microdomainassociated protein, Arabidopsis Flot1, is involved in a clathrinindependent endocytic pathway and is required for seedling development. Plant Cell 24(5):2105-2122

Lin T-Y, Lin Y-W, Lu C-W, Huang S-K, Wang S-J (2013) Berberine inhibits the release of glutamate in nerve terminals from rat cerebral cortex. PLoS One 8(6):e67215

Lindsay WL (1876) Mind in plants. J Ment Sci 21(96):513-532

Linson A, Calvo P (2020) Zoocentrism in the weeds? Cultivating plant models for cognitive yield. Biol Philos 35:49

Maher C (2020) Experiment rather than define. Trends Plant Sci 25(3): 213-214

Matzke AJM, Lin W-D, Matzke M (2019) Evidence that ion-based signaling initiating at the cell surface can potentially influence chromatin dynamics and chromatin-bound proteins in the nucleus. Front Plant Sci 10:1267

Mesaroș A (2014) Aristotle and animal mind. Procedia Soc Behav Sci 163:185-192

Mescher MC, De Moraes CM (2015) Role of plant sensory perception in plant-animal interactions. J Exp Bot 66(2):425-433

Mo M, Yokawa K, Wan Y, Baluška F (2015) How and why do root apices sense light under the soil surface? Front Plant Sci 6:775

Mousavi SAR, Chauvin A, Pascaud F, Kellenberger S, Farmer EE (2013) Glutamate receptor-like genes mediate leaf-to-leaf wound signalling. Nature 500:422-426

Muday GK, Brown-Harding H (2018) Nervous system-like signaling in plant defense. Science 361:1068-1069

Pavel MA, Petersen EN, Wang H, Lerner RA, Hansen SB (2020) Studies on the mechanism of general anesthesia. Proc Natl Acad Sci U S A 117(24):13757-13766

Pavlovič A, Libiaková M, Bokor B, Jakšová J, Petřík I, Novák O, Baluška F (2020) Anaesthesia with diethyl ether impairs jasmonate signalling in the carnivorous plant Venus flytrap (Dionaea muscipula). Ann Bot 125(1):173-183

Qiu X-M, Sun Y-Y, Ye X-Y, Li Z-G (2020) Signaling role of gutamate in plants. Front Plant Sci 10:1743

Ramesh SA, Tyerman SD, Xu B, Bose J, Kaur S, Conn V, Domingos P, Ullah S, Wege S, Shabala S, Feijó JA, Ryan PR, Gilliham M (2015) GABA signalling modulates plant growth by directly regulating the activity of plant-specific anion transporters. Nat Commun 6:7879

Ramesh SA, Tyerman SD, Gilliham M, Xu B (2017) $\gamma$-Aminobutyric acid (GABA) signalling in plants. Cell Mol Life Sci 74(9):15771603

Reber A, Baluška F (2020) Cognition in some surprising places. Biochem Biophys Res Commun, 531:In press

Reyer A, Häßler M, Scherzer S, Huang S, Pedersen JT, al-Rasheid KAS, Bamberg E, Palmgren M, Dreyer I, Nagel G, Hedrich R, Becker D (2020) Channelrhodopsin-mediated optogenetics highlights a central role of depolarization-dependent plant proton pumps. Proc Natl Acad Sci U S A 117(34):20920-20925
Rodrigo-Moreno A, Bazihizina N, Azzarello E, Masi E, Tran D, Bouteau F, Baluška F, Mancuso S (2017) Root phonotropism: early signalling events following sound perception in Arabidopsis roots. Plant Sci 264:9-15

Roohi Z, Imanpoor MR (2015) The efficacy of the oils of spearmint and methyl salicylate as new anesthetics and their effect on glucose levels in common carp (Cyprinus carpio L., 1758) juveniles. Aquaculture 437:327-332

Sopory S (2019) Sensory biology of plants. Springer Nature

Stahlberg R (2006) Historical overview on plant neurobiology. Plant Signal Behav 1:6-8

Stolarz M, Krol E, Dziubinska H, Kurenda A (2010) Glutamate induces series of action potentials and a decrease in circumnutation rate in Helianthus annuus. Physiol Plant 138:329-338

Stroebel D, Paoletti P (2020) Architecture and function of NMDA receptors: an evolutionary perspective. J Physiol In press

Taiz L, Alkon D, Draguhn A, Murphy A, Blatt M, Hawes C, Thiel G, Robinson DG (2019) Plants neither possess nor require consciousness. Trends Plant Sci 24(8):677-687

Takahashi H, Scott TK (1991) Hydrotropism and its interaction with gravitropism in maize roots. Plant Physiol 96(2):558-564

Toyota M, Spencer D, Sawai-Toyota S, Jiaqi W, Zhang T, Koo AJ, Howe GA, Gilroy S (2018) Glutamate triggers long-distance calciumbased plant defense signaling. Science 361:1112-1115

Trewavas AJ, Baluška F (2011) The ubiquity of consciousness. EMBO Rep 12(12):1221-1225

Tsuchiya H (2017) Anesthetic agents of plant origin: a review of phytochemicals with anesthetic activity. Molecules 22:1369

Volkov AG, Foster JC, Ashby TA, Walker RK, Johnson JA, Markin VS (2010) Mimosa pudica: electrical and mechanical stimulation of plant movements. Plant Cell Environ 33(2):163-173

Volkov AG, Reedus J, Mitchell CM, Tuckett C, Volkova MI, Markin VS, Chua L (2014) Memory elements in the electrical network of Mimosa pudica L. Plant Signal Behav 9(10):e982029

Vosshall LB, Carandini M (2009) Sensory systems. Curr Opin Neurobiol 19:343-344

Wang L, Li H, Lv X, Chen T, Li R, Xue Y, Jiang J, Jin B, Baluška F, Šamaj J, Wang X, Lin J (2015) Spatiotemporal dynamics of the BRI1 receptor and its regulation by membrane microdomains in living Arabidopsis cells. Mol Plant 8(9):1334-1349

Watt EE, Betts BA, Kotey FO, Humbert DJ, Griffith TN, Kelly EW, Veneskey KC, Gill N, Rowan KC, Jenkins A, Hall AC (2008) Menthol shares general anesthetic activity and sites of action on the GABA(A) receptor with the intravenous agent, propofol. Eur J Pharmacol 590(1-3):120-126

Weiland M, Mancuso S, Baluska F (2016) Signalling via glutamate and GLRs in Arabidopsis thaliana. Funct Plant Biol 43:1-25

Weiler EW (2003) Sensory principles of higher plants. Angew Chem Int Ed 42(4):393-411

Weinrich M, Worcester DL (2013) Xenon and other volatile anesthetics change domain structure in model lipid raft membranes. J Phys Chem B 117:16141-16147

Witzany G, Baluška F (2012) Life's code script does not code itself. The machine metaphor for living organisms is outdated. EMBO Rep 13(12):1054-1056

Wudick MM, Michard E, Nunes CO, Feijó JA (2018) Comparing plant and animal glutamate receptors: common traits but different fates? J Exp Bot 69(17):4151-4163

Xing J, Li X, Wang X, Lv X, Wang L, Zhang L, Zhu Y, Shen Q, Baluška F, Šamaj J, Lin J (2019) Secretion of phospholipase D $\delta$ functions as a regulatory mechanism in pant innate immunity. Plant Cell 31(12): $3015-3032$ 
Xue Y, Xing J, Wan Y, Lv X, Fan L, Zhang Y, Song K, Wang L, Wang X, Deng X, Baluška F, Christie JM, Lin J (2018) Arabidopsis blue light receptor phototropin 1 undergoes blue light-induced activation in membrane microdomains. Mol Plant 11(6):846-859

Yokawa K, Fasano F, Kagenishi T, Baluška F (2014) Light as stress factor to plant roots - case of root halotropism. Front Plant Sci 5:718

Yokawa K, Kagenishi T, Pavlovic A, Gall S, Weiland M, Mancuso S, Baluška F (2018) Anaesthetics stop diverse plant organ movements, affect endocytic vesicle recycling and ROS homeostasis, and block action potentials in Venus flytraps. Ann Bot 122(5):747-756

Yokawa K, Kagenishi T, Baluška F (2019) Anesthetics, anesthesia, and plants. Trends Plant Sci 24(1):12-14
Žárský V (2015) Signal transduction: GABA receptor found in plants. Nat Plants 1:15115

Zhao X, Li R, Lu C, Baluška F, Wan Y (2015a) Di-4-ANEPPDHQ, a fluorescent probe for the visualisation of membrane microdomains in living Arabidopsis thaliana cells. Plant Physiol Biochem 87:5360

Zhao X, Zhang X, Qu Y, Li R, Baluška F, Wan Y (2015b) Mapping of membrane lipid order in root apex zones of Arabidopsis thaliana. Front Plant Sci 6:1151

Publisher's note Springer Nature remains neutral with regard to jurisdictional claims in published maps and institutional affiliations. 